DOI: $10.2478 /$ pof-2018-0019

VOLUME 10, ISSUE 2, 2018

ISSN: 2036-5438

\title{
Legislative Functions of Second Chambers in Federal Systems
}

by

\author{
Anna Gamper*
}

Perspectives on Federalism, Vol. 10, issue 2, 2018 


\begin{abstract}
Legislative functions of federal second chambers are not a homogeneous set of powers, but require comparison and classification. First, the paper will examine the legislative functions of the second chambers of those European states that have a federal or quasifederal character (Austria, Belgium, Bosnia and Herzegovina, Germany, Italy, Russia, Spain, Switzerland, United Kingdom). Second, the paper addresses the normative concept of the legislative functions of federal second chambers: what is the particularly federal rationale behind these legislative powers, and are there other constitutional rationales as well? Do some legislative functions serve purposes of federalism better than others and does a dichotomy between 'weak-form' and 'strong-form' veto powers apply in this context? This will also require some discussion on whether perfect or imperfect bicameralism and the requirements of internal decision-making play a role in this regard.
\end{abstract}

\title{
Key-words
}

bicameralism, federalism, legislative functions, second chambers 


\section{Introduction}

'In republican government, the legislative authority necessarily predominates. The remedy for this inconveniency is to divide the legislature into different branches; and to render them, by different modes of election and different principles of action, as little connected with each other as the nature of their common functions and their common dependence on the society will admit.'

It was James Madison who thus explained bicameralism in federal context. But even earlier than the era of federalism, bicameralism connoted legislatures with two branches (Luther 2006: 3; Shell 2001: 18; Uhr 2008: 474). In accordance with this concept, the term 'second chamber' does not indicate a qualitative standard - as the terms 'lower' or 'upper' chamber -, but refers to the chronology of legislative processes. ${ }^{\text {II }}$ While it is true that second chambers are today vested with much more than just legislative functions - as indeed first chambers are -, legislation is still what matters most. ${ }^{\text {III }}$ This is especially so in the case of federal second chambers, since federalism requires the participation of the component units in the very process that determines, inter alia, their own status and future (Palermo and Kössler 2017: 164). In states governed by the rule of law, this requires participation in legislation, including, above all, constitutional legislation. But even though there is a plethora of literature on second chambers, including those existing in federal systems, little attention has been paid to their legislative functions as a particular constitutional species that requires a more differentiated analysis.

Legislative functions of federal second chambers are, however, not a homogeneous set of powers, but require comparison and classification, which this paper undertakes. First, an empirical survey will examine the legislative functions of the second chambers of those European states that have a federal or strongly regionalised character (Austria, Belgium, Bosnia and Herzegovina, Germany, Italy, Russia, Spain, Switzerland, United Kingdom), which is mainly due to the law-making powers of their respective component units. Moreover, with the exception of the UK's House of Lords (which is still included in this study due to the strong degree of autonomy in the devolved regions), all of these second chambers are organisationally and/or functionally strongly related to the subnational level, even though this may have little impact in political practice. Second, the paper addresses the normative concept of the legislative functions of federal second chambers: what is the 
particularly federal rationale behind these legislative powers, and are there other constitutional rationales as well? Do some legislative functions serve purposes of federalism better than others and is a dichotomy between 'weak-form' and 'strong-form' veto powers useful in this context? This will also require some discussion on whether perfect or imperfect bicameralism and the requirements of internal decision-making play a role in this regard.

\section{Types of Legislative Functions}

In almost all federal states, federal parliaments have a bicameral structure (Watts 2008: 147; 2010: 33-34); in some of these states, even the component units' parliaments, or part of them, are bicameral. ${ }^{\mathrm{IV}}$ At the federal level, the respective second chamber represents the component units, while the first chamber, as a rule, represents federal citizens directly.

In a majority of cases, second chambers are constitutionally vested with fewer and weaker powers than first chambers (Patterson and Mughan 2001: 41-44). The same observation applies to federal second chambers, also with regard to their legislative functions (Watts 2010: 39-40). All federal second chambers participate in legislation to some degree; however, they may or may not have other, non-legislative functions, such as, inter alia, the parliamentary scrutiny of the executive, appointments, impeachment, constitutional interpretation, international treaties, EU affairs or the dissolution of bodies pertaining to the component units (Watts 2008: 153-154; Luther 2006: 25-28; Palermo and Kössler 2017: 193-200). Their core function nevertheless is legislation.

Legislative functions are sometimes equalised with veto rights in legislative processes. From a broader perspective, however, there is a much more complex variety of legislative functions, ${ }^{\mathrm{V}}$ such as the following:

(1) the right to enact quasi-legislative rules autonomously, which mostly applies to the second chamber's Standing Orders

(2) the right to initiate legislation

(3) the right to veto bills passed by the first chamber, with different ensuing options:

(a) an absolute veto that successfully stops the enactment of the bill

(b) a suspensive veto that may be overruled by the first chamber 
(c) a suspensive veto that is submitted to a mediation committee for final resolution

(4) the right to modify bills passed by the first chamber, irrespective of the consequence

(5) the right to demand a referendum on a bill passed by the first chamber

(6) the right to appeal to (constitutional) courts for the pre-enactment scrutiny of a bill

(7) the right to challenge enacted laws before (constitutional) courts

The legislative functions of federal second chambers may have a 'positive' or 'negative' impact on legislation - not in a moral sense, but with regard to the question of whether law is created or abolished (or prevented from being created, respectively). ${ }^{\mathrm{VI}}$ Federal second chambers may thus appear as positive or negative law-making bodies, irrespective of whether their 'positive' or 'negative' act is decisive or not. ${ }^{\mathrm{VII}}$ Some of these rights have, however, a Janus-faced character inasmuch as it depends on their exercise whether they contribute to a law in a 'positive' or 'negative' sense. For example, veto rights are mostly connoted as 'negative' legislative function, but this depends on the kind of veto: a suspensive veto could perhaps entail further discussion and a modification of a bill that is ultimately enacted. Vice versa, even the right to initiate legislation which appears to be the paradigm of 'positive' legislation may, in effect, bear a negative character inasmuch as the second chamber could propose a repealing law with the sole effect of abolishing an existing law.

\section{Empirical Survey}

The comparison between the federal second chambers selected for this study shows that, even though all of them participate in legislative functions in principle, they usually do not take part in the same type of legislative functions. ${ }^{\text {VIII }}$

All of the (quasi-)federal second chambers ${ }^{\mathrm{IX}}$ selected for this survey are vested with the right to initiate legislation (in all or some fields) ${ }^{\mathrm{x}}$ and with the right to enact their own Standing Orders. ${ }^{\mathrm{XI}}$ As far as the possibility of challenging federal laws before constitutional courts is concerned, all of these second chambers except the House of Lords, ${ }^{\mathrm{XII}}$ the Italian Senato and the Swiss Ständerat ${ }^{\mathrm{XII}}$ are entitled to do so. ${ }^{\mathrm{XIV}}$ The second chambers in Italy, 
Switzerland and Bosnia and Herzegovina have absolute veto powers regarding all kinds of legislation (even though a mediation process may apply previously) due to the perfectly bicameral system. All other federal second chambers only enjoy absolute veto powers in some fields of legislation or are not even entitled to exercise a (any) veto at all, where certain areas of legislation - typically, if they do not particularly concern the component units - are reserved to the first chamber. ${ }^{\mathrm{XV}}$ Some significant differences apply with regard to suspensive veto rights, since in some cases, such as Austria, ${ }^{\mathrm{XVI}}$ this simply amounts to a vote that can be overruled by the first chamber in a repeated decision. ${ }^{\mathrm{XVII}}$ In other cases, such as Belgium $^{\mathrm{XVIII}}$, Spain ${ }^{\mathrm{XIX}}$ or the UK, however, the respective second chambers may not just disapprove a bill, but actively propose modifications to a bill that have to be considered (though not necessarily adopted) by the first chamber. A similar option is a joint mediation committee consisting of members of both chambers, such as in Germany, Switzerland, Russia or Spain, ${ }^{\mathrm{Xx}}$ namely a body in which negotiations take place and in which compromises on bills may be found that are submitted to the chambers for their approval or rejection in a prolonged legislative process. ${ }^{\mathrm{XXI}}$ The compared systems differ as to whether mediation is only provided for certain pieces of legislation and what the entailing consequences are if the federal second chamber does not approve the compromise submitted by the mediation committee - in particular, whether it may finally be overruled by the first chamber or not.

Both pre-legislative scrutiny on the appeal of a second chamber ${ }^{\mathrm{x} I I}$ and the possibility ${ }^{\text {XXIII }}$ that the federal second chamber may separately demand a referendum on certain bills are only provided in rare cases.

\section{Weak-form and Strong-form Powers: a Meaningful Concept for Federal Second Chambers?}

The core of legislative functions of the compared federal second chambers consists of the right to initiate legislation and the right to veto bills passed by the first chamber. The traditional classification of second chambers as 'strong' or 'weak' is primarily concerned with their veto powers: the more (absolute) veto powers they have, and the wider the fields are to which they apply, the stronger these chambers are considered to be. This assessment emanates from the view that federal second chambers serve to defend and protect the 
component units from federal interference. At first glance, an absolute veto power is surely the most efficient tool to accomplish this function since it successfully prevents bills from being enacted. Whether this is a successful model in the long run, is a different question though. Transplanting Tushnet's ${ }^{\text {XxIv }}$ categories of weak-form and strong-form judicial review onto the legislative functions of federal second chambers, even weak-form functions may have certain strengths. While the exercise of strong-form veto rights may produce blockades and conflicts between the chambers, weak-form rights such as suspensive veto rights or (federal second chambers' or mediation committees') rights to propose modifications to bills passed by the first chamber may trigger political dialogue. Even a 'mere' suspensive veto, that simply entails a second resolution by the first chamber on whether to uphold the original bill, might stimulate the first chamber to further discuss and reflect on the content of a bill. Weak-form powers of federal second chambers could thus promote the efficiency of legislative procedures, political compromise and cooperation between both chambers. Absolute veto powers amount to a 'yes-no' vote which, depending on the political decision in the second chamber, either absolutely impede or unconditionally accept bills passed by the first chamber. They do not allow for a third option, namely to reflect, discuss and eventually modify such bills. Indirectly, the mere threat of an absolute veto could, however, also motivate the first chamber to pre-consider the second chamber's interests in the early phase of a legislative process. Moreover, federal second chambers might be vested with absolute veto rights and still not use them in order to protect the component units if their political intentions are in line with those of the respective first chambers. ${ }^{\mathrm{XxV}}$ And even the exercise of an absolute veto could be followed by a total restart or second stage $\mathrm{xxvI}^{\mathrm{of}}$ the legislative process.

Weak-form legislative powers are, however, not sufficient safeguards for the protection of component unit interests, since the first chamber may not be willing to enter into negotiations or to reach a compromise with the second chamber if it is not formally required to do so. It largely depends on the concrete political attitudes of both chambers whether suspensive vetoes sufficiently protect component unit interests and whether they really enable serious dialogue between the chambers.

Neither absolute nor suspensive veto powers can, therefore, guarantee that a federal second chamber either represents component unit interests efficiently or, in turn, may expect the first chamber to reach a compromise 'voluntarily'. The only certainty seems to 
be that absolute veto powers will serve as better protective shields than suspensive veto powers if a federal second chamber wants to use that shield. For the purposes of federalism, moreover, absolute veto powers seem to be advisable at least in cases where the federal constitution is amended or where laws with particular focus on the component units are concerned.

Still, theory on second chambers should be more mindful of the question of what the federal rationale behind federal second chambers really is. If the rationale is more or less understood to be the protection and defense of the component units, veto rights - and, among these, absolute veto rights in particular - will be considered to be the strongest and most important instruments pertaining to a federal second chamber's legislative functions. Using absolute veto rights, federal second chambers would not even need the power to challenge laws before constitutional courts, because they could perfectly well prevent them from being enacted at all - and, what is more, not just for constitutional reasons. If, however, the federal rationale behind these chambers is rather understood to lie in their active contribution to the design of federal laws (with whatever content) and to advise, reflect or instigate further discussion, the right to initiate bills, the right to propose modifications and, indeed, even 'mere' suspensive veto powers might be seen as the more constructive tool. ${ }^{\text {XXvII }}$

It would be a misconception, however, to suggest that imperfect bicameralism would be a better option for federal systems than perfect bicameralism. Imperfect bicameralism means that (usually) the second chamber, and (usually) not the first chamber, has fewer and weaker powers (Patterson and Mughan 2001: 41-44). With regard to legislative powers, this implies that the second chamber has fewer and weaker powers in the legislative process than the first. This deficit may apply to the initiative power as well as the respective type of veto power or any other of the aforementioned legislative functions.

When the Italian Government first proposed its ideas on a new Senate - which was finally rejected by Italian voters in the constitutional referendum of 4 December 2016 , XXVIII the suggestion was made that the new Senate would be better suited to regional or quasi-federal needs when compared to the prevailing system of perfect bicameralism. ${ }^{x x x}$ However, what they planned to introduce was not a 'federal' Senate but a Senate with reduced powers (and a new organization); indeed powers so reduced that one could seriously question whether to uphold the bicameral system at all. Put very simply, purposes 
of federalism are not served by the mere reduction of a second chamber's powers, even when the remaining powers are embedded in a federal context - unless the 'lost' powers were given to alternative bodies of component representation.

\section{The Federal Rationale behind Legislative Powers of Federal Second Chambers}

In federal systems, self-rule, namely the legislative, administrative and judicial competences of the component units, must be accompanied by shared rule. ${ }^{\mathrm{Xx}}$ Shared rule allows the component units to take part in federal legislation on any or at least some matters that affect them particularly. This latter participation is the more important when it comes to federal constitutional law-making or other pieces of federal legislation that concern the very existence and status of the component units as such. Thus, federalism requires that the component units have a decisive say in the determination of their own future, although shared rule and the legislative powers emanating from it is not necessarily restricted to this issue alone. Accordingly, the common federal rationale behind the legislative powers of federal second chambers is the possibility to co-determine federal legislation.

The discussion on the federal function of legislative powers of federal second chambers, however, does not stop at the threshold of the power question as such. Early theorists, like the authors of the Federalist Papers, ${ }^{\text {xxI }}$ focused on the second chamber's powers vis-à-vis the first chamber, but also on the kind of (symmetric or asymmetric) representation of the component units, which has coined the mainstream of theory on bicameralism in federal systems. However, the representation of component units has usually been regarded as some sort of 'blocked' interest, realised through the initiation of laws as well as the vetoing or amending of bills. The issue of heterogeneity between the component units has mostly been treated from an organizational perspective, i.e. whether the component units are represented by an absolutely equal number of delegates or not. $^{\text {XXXII }}$ 
It is questionable, however, whether the federal function of legislative powers of second chambers is adequately treated by this view. Rather, the question of how decisions in the federal second chamber are made also seems to be of interest here: can we, when discussing the federal function of federal second chambers and their legislative powers, simply regard the component units as some sort of consolidated body that is (symmetrically or asymmetrically) represented in the federal second chamber? While theory has lately attached much weight to other issues of asymmetric federalism, ${ }^{\text {XxxIII }}$ less thought has been given to the internal decision-making of federal second chambers. Ultimately, it is the protection of individualism that lies at the bottom of asymmetric federalism. It will be adequate, therefore, to also take the individual component unit view into account when the federal function of legislative powers of second chambers is examined.

Legislative powers of federal second chambers do not necessarily guarantee that they are truly exercised for purposes of federalism. This may be partly due to the politics of second chambers, since some federal second chambers merely operate in line with the interests of political parties, whatever their effects on federalism are (Palermo and Kössler 2017: 185). But federal legislation may also have different implications on the component units. While some of them (and their delegates in the federal second chamber respectively) may therefore agree with a bill, others may not.

Unlike the right to initiate laws, to which even individual members of parliament are often entitled, decision-making in the legislative process usually depends on majority votes. Unanimity, either between delegates or the component units' delegations, is not a typical requirement, even if in some cases qualified majorities apply. As a consequence, a single component unit will not be able to enforce its will even in federal second chambers where the component units are represented symmetrically. A qualified majority ensures, however, that the consent of more component units (and their respective delegates) is needed. The federal character of these majorities will be evident if they are required when federal legislation puts federalism at risk, e.g. when a federal constitutional bill targets the allocation of powers, the organisation or functions of the second chamber or other elements essential to the federal system (Kincaid 2005: 419). It will be less probable that a bill of centralistic purport is successful in the federal second chamber if a large majority of component units have to approve and not just some of them. On the other hand, qualified 
majorities may slow down or even produce deadlocks to the legislative process, since it will be more difficult to reach consensus between the delegates of the component units.

In this context, the direct participation of the component units either instead of or in addition to the involvement of the federal second chamber could be contemplated. ${ }^{\text {xxIV }}$ Direct participation means that each individual component unit is allowed to participate in the legislative process, that it has a direct say in the legislative process without being represented by a 'chamber' or similar institution. Normally, the component units in these cases decide on bills passed by the first or even the federal second chamber, but in some countries they may even initiate certain pieces of legislation. ${ }^{x x x v}$ The German model according to which members of the Länder governments sit in the Bundesrat seems to combine both approaches. Nevertheless, the Bundesrat is a body of its own, irrespective of whether its members have a 'double' function as members of the Länder governments and even though the German Bundesverfassungsgericht ${ }^{\mathrm{xxvI}}$ disqualified it as a 'second chamber of a uniform legislative organ which, on a level of parity with the first chamber, would decisively participate in the legislative process' ${ }^{\text {XxxvII }}$

Direct participation of the component units, however, neither excludes weighted voting nor does it necessarily require unanimity. It depends on the respective constitution whether each and every component unit has one and the same vote and whether decisions can only be taken unanimously or not. ${ }^{\text {XXXVIII }}$ The question of whether voting has a representative or directly democratic basis, does not matter in this context. It seems to be more usual, though, that the vote of the component unit is exercised by a representative body, such as the respective parliament, government or governor of that unit. However, federal constitutions might also provide (or empower the component constitutions to provide) that each component people expresses its will on a legislative matter in a referendum, as the Australian or Swiss Federal Constitution prescribe with regard to federal constitutional amendments. ${ }^{\text {xxxix }}$

From an empirical perspective, most federal constitutions establish federal second chambers, although they often do not provide for direct component unit participation in legislative processes. Where this is the case, however, it is largely the federal constitutional amendment process that is concerned (Palermo and Kössler 2017: 179-183): mostly, the need for approval by the federal second chamber is not replaced by direct participation, but the latter serves as an additional ingredient required for amendments to the federal 
constitution. ${ }^{\mathrm{XL}}$ In rarer cases, direct component unit participation is not required for federal constitutional amendments, but for ordinary federal laws in certain fields that are sensitive to component unit interests. ${ }^{\text {LLI }}$

A very special opportunity to allow the component units to participate in legislative processes is provided in Belgium ${ }^{\text {XLII }}$ and Bosnia and Herzegovina, ${ }^{\text {XLIII }}$ where the linguistic groups (Belgium) or ethnic groups (Bosnia and Herzegovina) are given particular representation even in the first chamber of the federal parliament (Bosnia and Herzegovina) or where special majorities of them are needed for certain legislation in the first chamber as well (both countries). ${ }^{\text {XIV }}$ While such a system is linked to multiethnic or multilinguistic societies, it has nevertheless not replaced federal second chambers and their legislative functions. A unique example is, moreover, the new EVEL (English Votes for English Laws) system in the House of Commons, where English (or English and Welsh) members are allowed to veto bills relating to England (or England and Wales). ${ }^{\text {XLV }}$

\section{Non-federal Rationales Behind Legislative Powers of Federal Second Chambers}

Lastly, it should not be forgotten that some non-federal rationales also lie behind the legislative functions of federal second chambers. Probably the most important of these was formulated by James Madison very clearly, namely that the Senate, 'as a second branch of the legislative assembly, distinct from, and dividing the power with, a first, must be in all cases a salutary check on the government ${ }^{\text {XLVI }}$ doubling 'the security to the people'. XLVII XLVIII The establishment of a federal second chamber was thus considered to be an 'introduction of legislative balances and checks'. ${ }^{\text {XLIx }}$ It is remarkable that second chambers have a stronger position in constitutional amendment procedures than in others, which also gives weight to the rigidity of a constitution (Palermo and Kössler 2017: 178-179). While non-federal second chambers, too, contribute to an 'internal' separation of powers vis-à-vis the first chamber within the legislative power, a federal second chamber additionally guarantees checks and balances within the vertical separation of powers.

The effectiveness of such checks and balances of course depends on many uncertain factors, such as party politics (Watts 2010: 41-43) and the selection and qualification of members and the type of legislative power. Other bodies committed to checks and 
balances may, however, be exposed to similar risks. ${ }^{\text {L }}$ This is no compelling reason, therefore, why federal second chambers should not exercise checks and balances, ${ }^{\text {LI }}$ not only with regard to issues pertaining to federalism, but also other issues. One particular function that could be mentioned here is the pre-enactment scrutiny of bills regarding their constitutionality. ${ }^{\text {LI II }}$ Where federal second chambers may employ veto rights without being restricted to particular arguments related to federalism, they could indeed practice a kind of ex ante judicial review of legislation. ${ }^{\text {LIII }}$ Such a function cannot be achieved easily, though. Apart from the possible absence of a political intention to exercise this function, members would need to be qualified lawyers (as the former Law Lords of the House of Lords were) or at least to rely on adequate legal services - which is not often the case. ${ }^{\text {LV }}$ Normally, federal second chambers cannot themselves take on the role of quasi-constitutional courts. Even the Federalist Papers admit that it 'must be acknowledged that this complicated check on legislation may in some instances be injurious as well as beneficial' ${ }^{\mathrm{LV}}{ }^{\mathrm{C}}$ But federal second chambers could be given the right to appeal to a (constitutional) court for preenactment scrutiny of a bill. A reflected, well-argued veto against unconstitutional bills would not only enhance checks and balances, but also the rule of law. A related role could be the 'authentic' interpretation of the constitution, such as that exercised by the Ethiopian House of Federation. ${ }^{\text {LVI }}$

A final aspect to be considered here is democracy. Although even federal second chambers have been accused of limiting democracy vis-à-vis first chambers that are elected by all federal citizens, ${ }^{\text {LVII }}$ this view is short-sighted. Federalism and democracy are strongly intertwined principles, irrespective of whether the component units are represented by directly or indirectly elected delegates (Luther 2006: 22; Watts 2010: 43-45). Ultimately, the respective component peoples are represented in the second chamber, and these peoples are the demoi of which the federal demos, as represented by the first chamber, is composed. Whether the representation of the component peoples follows the same democratic pattern as the composition of the first chamber, may differ from system to system. But even the mandates belonging to a first chamber are not always distributed on a completely proportional basis, depending on the nationwide electoral system. While it is possible, therefore, that the first and second chamber follow different proportions or that a proportional model does not apply for the second chamber at all, it is, at any rate, an additional representative body of peoples and no oligarchic body. 


\section{Conclusions}

Legislative functions of component units, not just those within their own sphere of competences, but also those targeted at the co-determination of federal legislation, are indispensable ingredients of all federal systems. Whether they are exercised by a federal second chamber or directly by the component units, by other special representative bodies and in whatever (symmetric or asymmetric) composition, is rather a matter of choice. Still, federal second chambers have become the most regular type of a component representative body; they are, moreover, democratic bodies which cannot be said of all second chambers.

Leaving aside questions of political efficiency, which may turn out differently from system to system, one should be aware that legislative functions comprise much more than just the function of a veto player. Even though veto rights are important because they ultimately protect the very constitutional status of the component units, it is not the only legislative function that matters in a federal system. Inherent in these functions are, moreover, other, non-federal functions of constitutional importance. Whatever type of legislative function a federal second chamber exercises, its decision-making is, however, largely majoritarian. Even where the component units enjoy equal representation, the larger states will, according to the Federalist Papers, 'always be able, by their power over the supplies, to defeat unreasonable exertions of this prerogative of the lesser States'. ${ }^{\text {LIII }}$ That only larger component units are the 'true defenders' of federalism in federal law-making, may, however, be doubted.

\footnotetext{
* Anna Gamper is Professor of Public Law at the Department of Public Law, State and Administrative Theory at the University of Innsbruck, Austria. Thanks go to Mathias Eller for his editorial support.

${ }^{\text {I }}$ Federalist Papers No 51.

II An attribution of 'quality' is rather suggested by the term 'upper house'; see Uhr (2008: 478).

III Watts (2008: 153; 2010: 40), Palermo and Kössler (2017: 193). See, with some reservations, Patterson and Mughan (2001: 51-52) and Bradley and Pinelli (2012: 665-667).

IV With examples, Palermo and Kössler (2017: 137).

$\mathrm{V}$ In an even wider sense, the right to participate in the ascending phase of EU legislation, the approval of international treaties that amend domestic laws or functions that affect the government or parliaments of the component units (and, indirectly, their legislative powers), such as the notorious Art 155 of the Spanish Constitution or Art 100 of the Austrian Federal Constitutional Act, could be mentioned as well, but are neglected for the purposes of this paper. Outside Europe, the Ethiopian House of Federation's power to interpret the constitution in a 'quasi-authentic' manner is worth mentioning.

vi See, more generally on 'positive' and 'negative' lawmaking, Gamper (2016: 14).
} 
VII Kelsen's functional attribution of 'positive lawmaking' to parliaments and 'negative lawmaking' to constitutional courts (Kelsen 1929: 56) is, thus, too little differentiated.

VIII A general survey on the functions of federal second chambers is given by Watts (2008: 153-154; 2010: 3941) and Palermo and Kössler (2017: 178-200). Palermo and Kössler (2017: 178-193) further distinguish between 'constitutional amendments', 'territorial changes' and 'legislative functions' (apart from other, nonlegislative functions) as primary functions of federal second chambers. But both constitutional amendments and (possibly) territorial changes rely on legislative functions as well.

IX Sometimes, these powers are not just those of the federal second chamber as such, but of their individual members or committees; for the purposes of comparison, this difference is neglected here.

x Art 41 para 1 of the Austrian Federal Constitutional Act, Art 75 para 1 of the Belgian Constitution, Art 76 para 1 of the German Basic Law, Art 71 para 1 of the Italian Constitution, Art 87 para 1 of the Spanish Constitution, Art 160 para 1 of the Swiss Constitution, Art 104 para 1 of the Russian Constitution. With regard to the possibility of 'private members' bills proposed by members of the House of Lords under the 'unwritten' UK constitution see Russell (2006: 78). The Constitution of Bosnia and Herzegovina does not explicitly regulate the right of initiative, but refers to the respective Standing Orders of both chambers, each of which is empowered to initiate legislation.

XI Art 37 para 2 of the Austrian Federal Constitutional Act, Art 60 of the Belgian Constitution, Art IV Sec 3 para $\mathrm{b}$ of the Constitution of Bosnia and Herzegovina, Art 52 para 3 of the German Basic Law, Art 64 para 1 of the Italian Constitution, Art 72 para 1 of the Spanish Constitution, Art 101 para 4 of the Russian Constitution, Art 36 of the Swiss Parliament Act. See, with regard to the House of Lords' Standing Orders under the 'unwritten' UK constitution, Russell (2006: 76-77).

XII Due to the absence of a written constitution and a constitutional court with the power to review Acts of Parliament.

XIII Due to the absence of a constitutional court with the power to review federal laws on a formal basis.

XIV Art 140 para 1 no 2 of the Austrian Federal Constitutional Act, Art 93 para 1 no 2 a and para 2 of the German Basic Law, Art 2 no 3 of the Belgian Special Act on the Constitutional Court (against federal and component legislation), Art 125 para 2 of the Russian Constitution, Art 162 para 1 subpara a of the Spanish Constitution. Art VI Sec 3 of the Constitution of Bosnia and Herzegovina provides this possibility only against component legislation.

xv See, eg, Art 42 para 5 of the Austrian Federal Constitutional Act.

XVI Art 42 para 4 of the Austrian Federal Constitutional Act.

XVII From a wider comparative perspective, Russell (2012: 121-126).

xVIII Art 78 para 2 of the Belgian Constitution.

XIX Art 90 para 2 of the Spanish Constitution.

$\mathrm{xx}$ A special case of mediation within the first or second chamber due to its multiethnic composition is constituted by Art IV Sec 3 para $d$ and $f$ of the Constitution of Bosnia and Herzegovina.

XxI Palermo and Kössler (2017: 192-193). See, more generally, Russell (2012: 126-127).

xxir See Art 79 para 3 of the Spanish Organic Law 2/1979 on the Constitutional Court or, under very limited conditions, Art IV Sec 3 para $f$ of the Constitution of Bosnia and Herzegovina.

XXIII Art 44 para 3 of the Austrian Federal Constitutional Act (in case of so-called 'partial constitutional revisions'), Art 138 para 2 of the Italian Constitution (in case of constitutional amendments), Art 167 para 3 of the Spanish Constitution.

XxIV See, specifically, Tushnet (2008); furthermore Tushnet (2003: 2781-2802; 2006: 1-22; 2011: 321-333; 2013: 2249-2263).

xxv On the political inefficiency of several federal second chambers, Kincaid (2005: 430), Russell (2001a: 113115; 2001b: 66), Watts (2010: 40).

xxvi See, eg, Art 138 of the Italian Constitution.

XXVII On the importance of 'legislative activity', Patterson and Mughan (2001: 48-49).

XXVIII „Disposizioni per il superamento del bicameralismo paritario, la riduzione del numero dei parlamentari, il contenimento dei costi di funzionamento delle istituzioni, la soppressione del CNEL e la revisione del titolo V della parte II della Costituzione', G.U. n. 88 of 15 April 2016.

xxIx Critically, Gamper (2009: 229-236).

xxx On the importance of both aspects, Watts (2005: 322); see, with much detail, Palermo and Kössler (2017: 125-320).

xxxi See, in particular, Federalist No 22 and Nos 62-66. 
xxxil Gamper (2005: 153-165) with more references; Gamper (forthcoming).

xxxiII See, eg, Palermo et al (2009: 21-35), Palermo et al (2007: 9-21), Watts (2008: 125-130), Bußjäger (2017: 63-73).

Xxxiv On the representative, though often informal role of other intergovernmental bodies Palermo and Kössler (2017: 177-178).

xxxv See, with examples, Russell (2001a: 112) and Palermo and Kössler (2017: 179-183).

xxxvi BVerfGE 37, 363 (380); see also Palermo and Kössler (2017: 172).

XxxvII Similarly, Luther (2006: 4) and Palermo and Kössler (2017: 174). The difference between the 'senate model' and the 'council model' (Palermo and Kössler 2017: 165) has only limited significance here: it is mainly concerned with the question whether members of federal second chambers exercise legislative functions differently due to the mode of their selection.

xxxvIII See, with examples, Palermo and Kössler (2017: 179-183). The consent of each state is, eg, demanded by Art 5 US Constitution with regard to federal constitutional amendments depriving a state of its equal suffrage in the Senate.

xxxix See Palermo and Kössler (2017: 182-183).

XL In some cases, however, only the component units (directly) and not the federal second chamber co-decide on federal constitutional amendments; see Palermo and Kössler (2017: 179-183).

XLI See, eg, in Austria: Art 14b para 4, Art 94 para 2, Art 102 para 1 and 4, Art 130 para 2 no 3, Art 131 para 4, Art 135 para 1 B-VG.

XLII In some fields of legislation, Art 4 para 3 of the Belgian Constitution, to which other provisions refer, requires a law passed by a majority of the votes cast in each linguistic group in each House, on condition that a majority of the members of each group is present and provided that the total number of votes in favour that are cast in the two linguistic groups is equal to at least two thirds of the votes cast.

XLIII Art IV para 2 of the Constitution of Bosnia and Herzegovina, according to which the House of Representatives shall comprise 42 Members, two- thirds elected from the territory of the Federation, onethird from the territory of the Republika Srpska.

XLIV A particularly interesting case is constituted by Art IV Sec 3 para d (see also para e and f, with regard to special majorities in the Second Chamber) of the Constitution of Bosnia and Herzegovina, according to which the delegates and members shall make 'their best efforts' to see that the majority includes at least onethird of the votes of delegates or members from the territory of each entity. If a majority vote does not include one-third of the votes of delegates or members from the territory of each entity, the chair and deputy chairs shall meet as a commission and attempt to obtain approval within three days of the vote. If those efforts fail, decisions shall be taken by a majority of those present and voting, provided that the dissenting votes do not include two-thirds or more of the delegates or members elected from either entity.

XLV See, with more detail, Tierney et al (2017: 222-223).

XLVI Federalist No 62.

XLVII Federalist No 62.

XLVIII See also Uhr (2008: 485-487).

xuIx Federalist No 9.

L This is why particular professional qualification is usually required for constitutional judges despite their often 'political' appointment.

Li See also Baldwin (2001: 172-175), Luther (2006: 21).

LII On the safeguard-function of second chambers in constitutional matters, see also Russell (2011: 61-74).

LIII See James Madison in Federalist No 62: 'Another advantage accruing from this ingredient in the constitution of the Senate is, the additional impediment it must prove against improper acts of legislation.'

LIV In an extremely idealistic vision, James Madison (Federalist No 62) expects from a 'well-constituted' senate aids in order to overcome the 'blunders of our governments', 'all the repealing, explaining, and amending laws, which fill and disgrace our voluminous codes, but so many monuments of deficient wisdom'. Even though this reflective function of a second chamber seems to be highly-overestimated when compared to bicameralism in practice, it could nevertheless play an important role for good governance.

LV Federalist No 62.

LVI Art 62 para 1 of the Ethiopian Constitution. See also Watts (2008: 154).

LVII On this critique, Watts (2008: 154; 2010: 43-45) and Uhr (2008: 474).

LVIII Federalist No 62. 


\section{References}

- $\quad$ Baldwin Nicholas D.J., 2001, 'Concluding Observations', in Baldwin Nicholas D.J. and Shell Donald (eds), Second Chambers, Frank Cass, London, 171-180.

- Bradley Anthony W. and Pinelli Cesare, 'Parliamentarism', in Rosenfeld Michael and Sajó András (eds), The Oxford Handbook of Comparative Constitutional Law, Oxford University Press, Oxford, 650-670.

- Bußjäger Peter, 2017, Föderale Systeme, Jan Sramek Verlag, Wien.

- Gamper Anna, 2005, “Arithmetische” und "geometrische” Gleichheit im Bundesstaat', in Weber Karl and Wimmer Norbert (eds), Vom Verfassungsstaat am Scheideweg - FS Peter Pernthaler, Verlag Springer, Wien, 143166.

- Gamper Anna, 2009, 'Remodelling the Italian Senate: New Challenges for a Mixed Constitution?', Percorsi costituqionali, II(1): 229-236.

- Gamper Anna, 2016, Verfassungsgerichtsbarkeit und Gewaltenverbindung, Verlag Österreich, Wien.

- Gamper Anna, 2018, 'Suum Cuique Tribuere - a Common Narrative of Federalism and Equality?' (forthcoming).

- Kelsen Hans, 1929, 'Wesen und Entwicklung der Staatsgerichtsbarkeit', VVDStRL, V: 30-88.

- Kincaid John, 2005, 'Comparative Observations', in Kincaid John and Tarr Alan G. (eds), Constitutional Origins, Structure, and Change in Federal Countries. A Global Dialogue on Federalism, vol 1, McGill-Queen's University Press, Montreal, 409-448.

- Luther Jörg, 2006, 'The Search for a Constitutional Geography and Historiography of Second Chambers', in Luther Jörg, Passaglia Paolo and Tarchi Rolando (eds), A World of Second Chambers, Giuffrè Editore, Milan, 3-31.

- $\quad$ Palermo Francesco, Hrbek Rudolf, Zwilling Carolin and Alber Elisabeth (eds), 2007, Auf dem Weg zu asymmetrischem Föderalismus?, Nomos, Baden-Baden.

- $\quad$ Palermo Francesco, Zwilling Carolin and Alber Elisabeth (eds), 2009, Asymmetries in Constitutional Law. Recent Developments in Federal and Regional Systems, EURAC, Bozen.

- $\quad$ Palermo Francesco and Kössler Karl, 2017, Comparative Federalism, Hart, Oxford.

- Patterson Samuel C. and Mughan Anthony, 2001, 'Fundamentals of Institutional Design: The Functions and Powers of Parliamentary Second Chambers', in Baldwin Nicholas D.J. and Shell Donald (eds), Second Chambers, Frank Cass, London, 39-60.

- $\quad$ Russell Meg, 2001a, 'The Territorial Role of Second Chambers', in Baldwin Nicholas D.J. and Shell Donald (eds), Second Chambers, Frank Cass, London, 105-118.

- Russell Meg, 2001b, 'Responsibilities of Second Chambers: Constitutional and Human Rights Safeguards', in Baldwin Nicholas D.J. and Shell Donald (eds), Second Chambers, Frank Cass, London, 61-76.

- Russell Meg, 2006, 'The British House of Lords: A Tale of Adaptation and Resilience', in Luther Jörg, Passaglia Paolo and Tarchi Rolando (eds), A World of Second Chambers, Giuffrè Editore, Milano, 65-96.

- Russell Meg, 2012, 'Elected Second Chambers and Their Powers: An International Survey', The Political Quarterly, LXXXIII(1): 117-129.

- Shell Donald, 2001, 'The History of Bicameralism', in Baldwin Nicholas D.J. and Shell Donald (eds), Second Chambers, Frank Cass, London, 5-18.

- Tierney Stephen, Welikala Asanga and Daly Tom G., 2017, 'United Kingdom', in Albert Richard, Landau David, Faraguna Pietro and Drugda Simon (eds), 2016 Global Review of Constitutional Law, The Clough Center for the Study of Constitutional Democracy, Boston, 221-226.

- $\quad$ Tushnet Mark, 2003, 'Alternative Forms of Judicial Review', Michigan Law Review, CI(8): 2781-2802.

- Tushnet Mark, 2006, 'Weak-Form Judicial Review and “Core” Civil Liberties', Harvard Civil Rights-Civil Liberties Law Review, XLI(1): 1-22.

- $\quad$ Tushnet Mark, 2008, Weak Courts, Strong Rights, Princeton University Press, Princeton.

- Tushnet Mark, 2011, 'The rise of weak-form judicial review', in Ginsburg Tom and Dixon Rosalind (eds), Comparative Constitutional Law, Edward Elgar Publishing, Cheltenham/Northampton, 321-333. 
- Tushnet Mark, 2013, 'The Relation Between Political Constitutionalism and Weak-Form Judicial Review', German Law Journal, XIV(12): 2249-2263.

- Uhr John, 2008, 'Bicameralism', in Rhodes R.A.W., Binder Sarah A. and Rockman Bert A. (eds), The Oxford Handbook of Political Institutions, Oxford University Press, Oxford, 474-494.

- Watts Ronald L., 2005, 'Comparative Conclusions', in Majeed Akhtar, Watts Ronald L. and Brown Douglas M. (eds), Distribution of Powers and Responsibilities in Federal Countries. A Global Dialogue on Federalism, vol 2, McGill-Queen's University Press, Montreal, 322-350.

- Watts Ronald L., 2008, Comparing Federal Systems, 3 $3^{\text {rd }}$ edition. McGill-Queen's University Press, Montreal.

- Watts Ronald L., 2010, 'Federal Second Chambers Compared', in Hrbek Rudolf (ed), Legislatures in Federal Systems and Multi-Level Governance, Nomos, Baden-Baden, 33-45. 